\title{
Mutation in the S4 segment of the adult skeletal sodium channel gene in an Italian Paramyotonia Congenita (PC) family
}

\author{
Sansone V.*, Rotondo G.*, Ptacek L.J.**, Meola G.* \\ * Divisione di Neurologia I, Università di Milano, Ospedale Clinicizzato San Donato - San Donato \\ Milanese, Milano, Italy; ** Department of Neurology and Human Genetics, University of Utah, Salt \\ Lake City, UT 84132
}

The periodic paralyses are a group of autosomal dominant muscle diseases sharing the common feature of episodic stiffness and weakness, usually occurring with muscle cooling (as in the case of paramyotonia congenita, PC phenotype) or changes in extracellular $K+$ levels resulting from various precipitating factors (hyperkalemic periodic paralysis, HYPP and hypokalemic periodic paralysis, HypoPP).

It is now known that HYPP maps to chromosome $17 q$, and that PC and a form of myotonia congenita without periodic paralysis also map to the $17 q$ locus, thus indicating that they derive from allelic variants. So far, these disorders have been described in various ethnic groups but, to our knowledge, have never been reported in Italy.

We describe a mutation in an 54 segment of the adult skeletal muscle sodium channel in a clinically-defined Italian family that leads to the paramyotonia congenita $(P C)$ phenotype with dominant autosomal inheritance and temperaturerelated symptoms (regional weakness following cooling and exercise), present since childhood in all of the affected family members.

Key Words: myotonia — sodium channel — mutation — paramyotonia congenita - mexiletine.

\section{Introduction}

The periodic paralyses are a group of autosomal dominant muscle diseases in which attacks of paralysis and myotonia may occur spontaneously or be precipitated by specific factors including

This study was supported by a grant from MURST $60 \%$ given to Prof. G. Meola. exercise, alterations in extracellular potassium levels and muscle cooling [22].

In hyperkalemic periodic paralysis (HYPP), the symptoms and signs are worsened by elevated serum potassium levels (thus making it possible to distinguish such patients from those with hypokalemic periodic paralysis, HypoPP) [7].

In another form of periodic paralysis, $P C$, the paralysis is temperature-sensitive and usually occurs with muscle cooling. Cold-induced, pro- 
longed, localized myotonia and subsequent transient weakness are the hallmarks of PC. Muscle activity aggravates $\mathrm{PC}$-associated myotonia (paradoxical myotonia) in contrast to the improvement with exercise that occurs in patients with other myotonic disorders (classic myotonia). Most PC patients demonstrate some degree of myotonic worsening with $\mathrm{K}^{+}$loading. However, in some cases the attacks of weakness are associated with normo- or hypokalemia [21], even though there are patients with the features of both HYPP and PC $[24,27]$.

Electrophysiological investigations of HYPP and PC muscle in vitro have revealed an alteration in muscle membrane sodium conductance $[26,15]$, suggesting that sodium channels are involved in the pathogenesis of periodic paralysis $[16,12]$. This is supported by the genetic linkage of SCN4A (the gene encoding the adult isoform of the Na channel) to HYPP and PC. The unique features of PC suggest that one or more mutations in SCN4A, different from those causing HYPP, might be responsible for the disorder [7, $19,13,5,23,10]$.

In the present series of experiments, single strand conformation polymorphism analyses were carried out in an Italian PC family to ascertain whether the PC phenotype expressed according to an autosomal dominant pattern of inheritance was effectively due to an alteration in the $\$ 4$ segment of the adult skeletal sodium channel, and whether this corresponded to one of the known mutations so far described $[20,25,17,5,6]$.

\section{Patients}

\section{Case I}

This patient (V-2) is a 52-year-old woman who has experienced cold-induced stiffness since infancy. On exposure to cold, her hands, feet and orbicularis oculi become stiff, cramped and slightly weakened for several hours after the stiffening event. There is no correlation with carbohydrate or liquorice ingestion, fasting or physical exercise. The patient has a previous history of thyroid involvement (hyperthyroidism, well compensated by substitution therapy after partial removal of the gland) and allergy to a number of antibiotics and anti-phlogistic drugs.

The symptoms and signs have never become lifethreatening, but the complaint is such that the patient has to limit all outdoor activities during winter-time and, in general, avoid any excessive cooling of her hands by normally using warm water from the tap. The patient came to our observation when she was treated with a beta-agonist and a thiazid diuretic (chlorthalidone) which failed to prevent the attacks.

Neurological examination showed a general hypertrophy, which was more evident in the gastrocnemius of both legs. The muscle of the antero-lateral aspect of the legs was instead moderately hypotrophic (the tibial crest was evident). Mechanical percussion of the right thenar eminence suggested a slight myotonic phenomenon.

\section{Case 2}

This patient (IV-5) is a 63-year-old man who firstnoticed stiffness in his hands at the age of 30 , around the time he started working as a butcher. $\mathrm{He}$ could not enter the cold-chamber because the stiffness and cramping of his hands was so marked that he was obliged to put down what he was holding and rest his hands for a half-hour following the stiffening event. No treatment was ever tried.

Neurological examination was completely normal.

\section{Case 3}

This patient (Vl-2) is a 31-year-old woman who is completely asymptomatic except for a mild degree of general weakness during the winter. No stiffening event has ever been described.

Neurological examination revealed a general hypertrophy that was more evident in the gastrocnemius of both legs, but no other sign of muscle involvement was observed.

\section{Case 4}

This patient (VI-3) is a 21-year-old man who has experienced muscle stiffening since childhood. The orbicularis oculi are mainly affected, but the complaint was disturbing only when he failed to protect his face with a scarf during excessively low temperatures. No other symptom was described until he reached 17-18 years of age, when he started experiencing mild stiffness in his hands. These disorders are not associated with any form of muscle weakness and he also practices judo. Neurological examination revealed general hypertrophy but no signs of muscle involvement.

\section{Case 5}

This patient (VI-4) is a 19-year-old man who is the most affected member of the family. Since the age of 14 , he was often obliged to stop driving his scooter because of his inability to open his hand to disengage the clutch or because he couldn't keep his eyes sufficiently open to drive properly. Sometimes he is able to ward off the event by means of gentle exercise (i.e. opening and closing his hands or eyes) and by avoiding excessive exposure to cold; at other times, complete recovery requires several hours and occasionally a few days, especially because of a tran- 
sient form of weakness following the event. No myalgia, cramps, stiffening or weakness is experienced between attacks, and he practises judo at a high sporting level.

Neurological examination showed well-developed, almost "sculptured" muscles but no sign of muscle involvement.

\section{Materials and methods}

The family tree indicated in Figure 1 includes 34 members over VII generations, with 4 provenly affected individuals and 12 affected by history. Diagnosis was based on the history of the members of the I and III generation, and the history and direct evaluation of the members of the IV, $\mathrm{V}$ and VI generations. No data were available for the members of the II generation.

The patients described above underwent routine haematological tests to check for any abnormalities in electrolytes at rest and after potassium loading. This latter test was carried out according to Streib et al. [29]: after fasting the patient was given $4 \mathrm{~g}$ of $\mathrm{K}^{+}$to drink in an unsweetened solution and isometric muscle exercises were done for about 3 minutes after potassium loading. During the test, $\mathrm{K}^{+}$levels were examined at baseline (control, before $\mathrm{K}^{+}$loading) and every $30 \mathrm{~min}$ utes. Blood pressure and ECG recordings were also checked for any type of cardiac involvement. Electrophysiological recordings (EMG studies) were carried out under baseline conditions and after exposure to cold in accordance with standard protocols [12].

Muscle biopsies were performed on the left biceps brachii under local anaesthesia with the consent of the patient. The Cryostat sections $(10 \mu \mathrm{m}$ thick) were processed for histochemical analysis as previously described [4]. A battery of histological and histochemical reactions tests was applied (haematoxylin and eosin, modified Gomori trichrome, ATPase at $\mathrm{pH} \mathrm{9.4,4.6} \mathrm{and} \mathrm{4.3,} \mathrm{nicotin-}$ amide nucleotide dehydrogenase -NADH, succinic dehydrogenase -SDH, periodic acid Schiff PAS, phosphorylase, acid phosphatase and oil red O).

Genetic studies now allow a more precise correlation between phenotype and specific mutations to be made, and so genetic analyses were carried out in several individuals (V-2; VI-2, VI-3; VI-4) using single-strand conformation polymorphism analysis to define alleles specific to this PC family. These alleles were then sequenced to investigate whether the identified base-pair changes corresponded to one of the known amino acid substitutions in the $\$ 4$ helix of domain 4 in the adult skeletal muscle sodium channel.
Polymerase chain reaction was used to amplify DNA samples $\left(3\right.$ minutes at $94^{\circ} \mathrm{C} \times 1 ; 1$ minute at $94^{\circ} \mathrm{C}, 1$ minute at $72^{\circ} \mathrm{C} \times 30$ ). The reaction buffer contained $200 \mathrm{ng}$ of DNA, $0.5 \mu \mathrm{M}$ of each primer, $70 \mu \mathrm{M}$ of each deoxynucleoside triphosphate, $10 \mathrm{mM}$ Tris (pH 8.3), $50 \mathrm{mM} \mathrm{KCl}, 1.5 \mathrm{mM}$ $\mathrm{MgCl}_{2}, 0.01 \%$ gelatin, 0.25 Units of Taq polymerase and $0.1 \mu \mathrm{l}$ of $32 \mathrm{P} \mathrm{dCTP}(300 \mathrm{Ci} / \mathrm{mmol})$ in a volume of $10 \mu \mathrm{L}$. The PCR primers used to amplify segments S3-S5 of domain 4 were forward primer $5^{\prime}$ AGCGTCCTCACTAGCTTCTC$3^{\prime}$ and reverse primer $5^{\prime}$-TGCCCGACTCCTTCTTGAC-3'. Each sample was analyzed using primers that amplified about $70 \%$ of the sodium channel coding sequence.

Single strand conformation polymorphism (SSCP) analysis was then carried out. The PCR products were diluted in $50 \mu \mathrm{L}$ of a mixture containing $0.1 \%$ SDS and $10 \mathrm{mM}$ EDTA. This mixture was further diluted $1: 1$ with running buffer $(95 \%$ formamide, $20 \mathrm{mM}$ EDTA, $0.05 \%$ bromphenol blue, $0.05 \%$ xylene cyanol). The diluted samples were then denatured for 3 minutes at $94^{\circ} \mathrm{C}$ and kept on ice until $3.5 \mu \mathrm{L}$ of each sample was loaded on $5 \%$ polyacrylamide gels $(0.4 \mathrm{~mm})$. The reaction products were electrophoresed using two conditions: a $90 \mathrm{mM}$ Tris-borate (ph 7.5), $2 \mathrm{mM}$ EDTA gel at $4^{\circ} \mathrm{C}$ and a $90 \mathrm{mM}$ Tris-borate $(\mathrm{pH} \mathrm{7.5)}, 2 \mathrm{mM}$ EDTA, $10 \%$ glycerol gel at $25^{\circ} \mathrm{C}$. Electrophoresis was carried out at a constant power of $40 \mathrm{~W}$. The electrophoresed gels were transferred to Whatmann $3 \mathrm{MM}$ paper and dried on a vacuum slab dryer. Autoradiography was performed using Kodak X-Omat AR film and intensifying screens for 12-16 hours.

Aberrant SSCP bands were excised from the dried gels and the DNA was eluted in $100 \mu \mathrm{l}$ of distilled water. The samples were centrifuged for 1 minute. New oligonucleotides were synthesized and corresponded to the original primers used for PCR, which was then performed using these primers to amplify a $10 \mu 1$ aliquot of the eluted DNA as previously described [23]. The amplified products were resolved on $4 \%$ agarose gels, isolated from the gel with Geneclean TM (Bio 101, La Jolla, CA) and sequenced using the dideoxy termination method [28] with fluorescently tagged M13 universal or reverse sequencing primers on an Applied Biosystems model 373A DNA sequencer (Applied Biosystems, Foster City, CA).

\section{Results}

The results of all of the routine blood tests described above were within the normal range. Only Case 1 had slightly low levels of $\mathrm{K}+$ ions ( 3 $\mathrm{mEq} / \mathrm{L}$ ) due to the therapy she was undergoing; 


\section{PC FAMILY PEDIGREE}

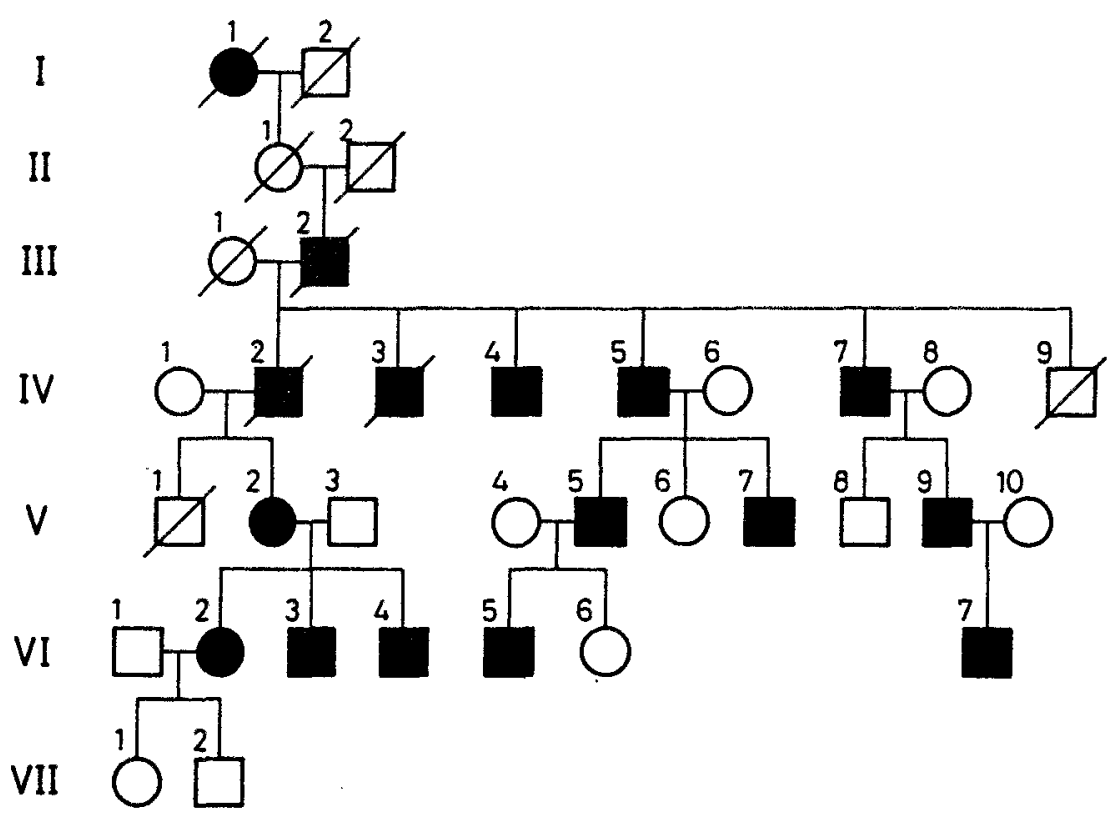

\footnotetext{
Legend

$V-2:$ case $1: 52$ - yr - old woman, affected, examined.

IV - 5 : case $2: 63$ - yr - old man, affected, examined.

$\mathrm{VI}-2$ : case $3: 31$ - yr - old woman, asymptomatic, examined.

$\mathrm{VII}$ - 1 : daughter of $\mathrm{VI}-2,5$ - yr - old girl, asymptomatic.

VII - 2 : son of $\mathrm{VI}-2,2-\mathrm{yr}$ - old boy, asymptomatic.

$\mathrm{VI}-3$ : case $4: 21$ - yr - old man, affected, examined.

$\mathrm{VI}-4$ : case $5: 19$ - yr - old man, most affected member, examined.

and : affected
}

Fig. 1. Family tree. The legend indicates the members of the family known to be affected by history or because directly examined.

Case 3 showed increased gamma-glutamil-transferase and total bilirubin content due to the presence of bilestones in the gall-bladder.

$K+$ loading gave similar results in all of our patients: 90 minutes after $\mathrm{K}^{+}$loading, none of the patients has experienced any kind of stiffness and all of the blood samples fell within normal range: $\mathrm{K}^{+}$never exceeded $4 \mathrm{mEq} / \mathrm{L}$. We interpreted this as a negative result.
The EMG studies carried out under baseline conditions and after exposure to cold showed evidence of myotonic and paramyotonic discharges in all of the examined muscles (upper and lower limbs) of all of our patients.

Muscle biopsies were performed in all of the affected members except Case 3 , who refused this exam. In the other patients, they showed signs of neurogenic involvement, especially in relation to 
type II muscle fibres.

Genetic analysis using the single-strand conformation polymorphism technique with primers from the human skeletal muscle sodium channel gene revealed an aberrant banding pattern that co-segregated with the disease in this family (Fig. 2). DNA sequencing of the aberrant band revealed a G-A transition at position 4420 in the sodium channel gene, which predicts an arginine - histidine change of position 1448 in sodium channel protein (Fig. 3).

\section{Discussion}

The periodic paralyses are a group of clinically heterogeneous syndromes in which patients present acute and reversible attacks of muscle weakness either spontaneously or after exposure to various triggering conditions, such as fasting, coldexposure and variations in $\mathrm{K}^{+}$blood levels [22]. Muscle function is altered and, although not lifethreatening because bulbar or respiratory muscles are rarely affected, this interferes with normal personal and professional activities. The classification of these disorders was initially based on blood $\mathrm{K}^{+}$level during attacks, but genetic and molecular genetic studies have now led to the identification of different groups of disorders: diseases associated with sodium-channel malfunction, such as HYPP and PC, and disorders due to alterations in chloride-channel function, including both dominant (Thomsen) and recessive (Becker) MC [9]. HypoPP is another form of periodic paralysis in which linkage to sodium-channel malfunction has been excluded $[8,3]$; recent studies have demonstrated that the dihydropyridine-sensitive skeletal muscle $\mathrm{Ca}^{2+}$ channel gene at $1 \mathrm{q} 31$ 32 is a plausible candidate for the location of the defect in this form of periodic paralysis [2].

The described disorders are closely related myopathic forms whose diagnosis is often impossible on clinical grounds alone. Although helpful in completing the clinical picture, EMG, $\mathrm{K}+$ loading tests and muscle biopsy studies, are often aspecific tools, but genetic analysis now makes it possibile to correlate phenotype to genotype when an evaluation of an entire family is possible. However, this approach does not help in the diagnosis of individual cases.

The family we describe exemplifies the difficulties of making a precise diagnosis on purely clinical grounds. From a clinical viewpoint, the history of some our patients contained elements typical of both HYPP (weakness was often more dominant than myotonia, and exercise reduced stiffening in some patients) and PC (with myotonia the predominant symptom and normal $\mathrm{K}+$

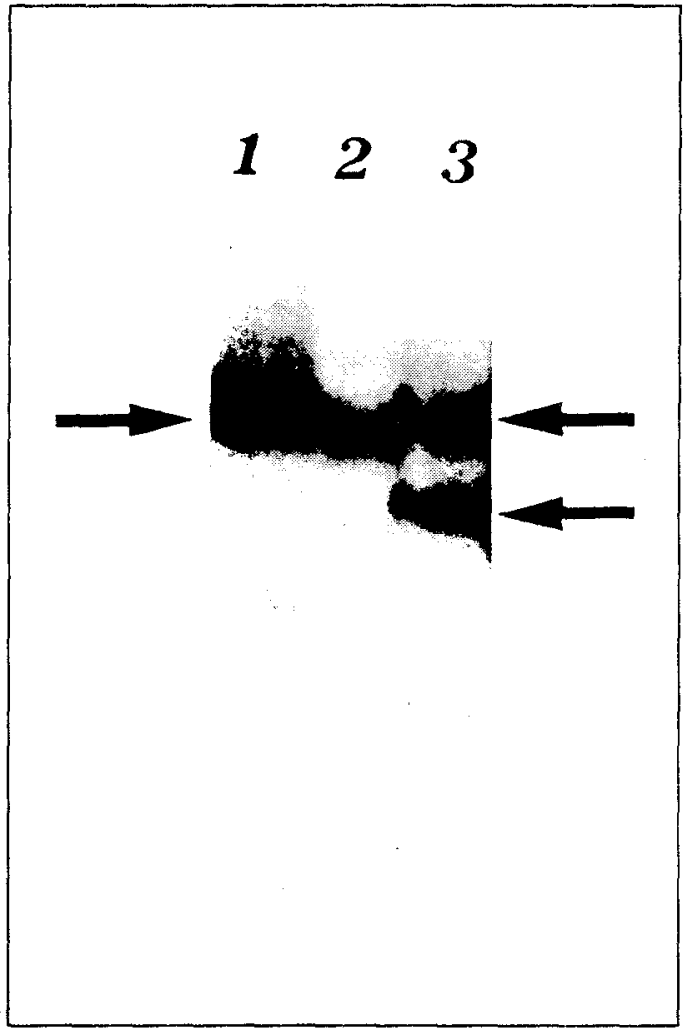

Fig. 2. SSCP conformers from the SCN4A gene specific to $P C$ patients. Lanes 1 and 2 of the SSCP autoradiograph correspond to controls and Lane 3 corresponds to Case 1. The upper arrows indicate normal bands; the aberrant band is indicated by the lower arrow. All of the examined patients had similar autoradiographs. (See text for methodological details).

levels during attacks); the EMG, $\mathrm{K}$ + loading tests and muscle biopsy studies were aspecific.

Single strand conformation polymorphism revealed a mutation in the sodium channel gene predicting a change (and therefore a malfunction) in the sodium channel protein responsible for the PC phenotype. This mutation occurs in the fourth membrane-spanning segment of domain 4 of the sodium channel protein (SCN4A) and alters the net charge in the region, but it is distinct from another that occurs at the same amino acid position but leads to the replacement of a basic arginine residue by a more neutral histidine (Fig. 3) [21]. The subunit involved in the S4 segment is the putative "voltage-sensor" of the channel. This segment has a high charge density due to the repeating motif of a basic amino acid at each position, and is thought to move in response to depolarization thus leading to channel opening. Although the cytoplasmic loop between domains 3 and 4 is 


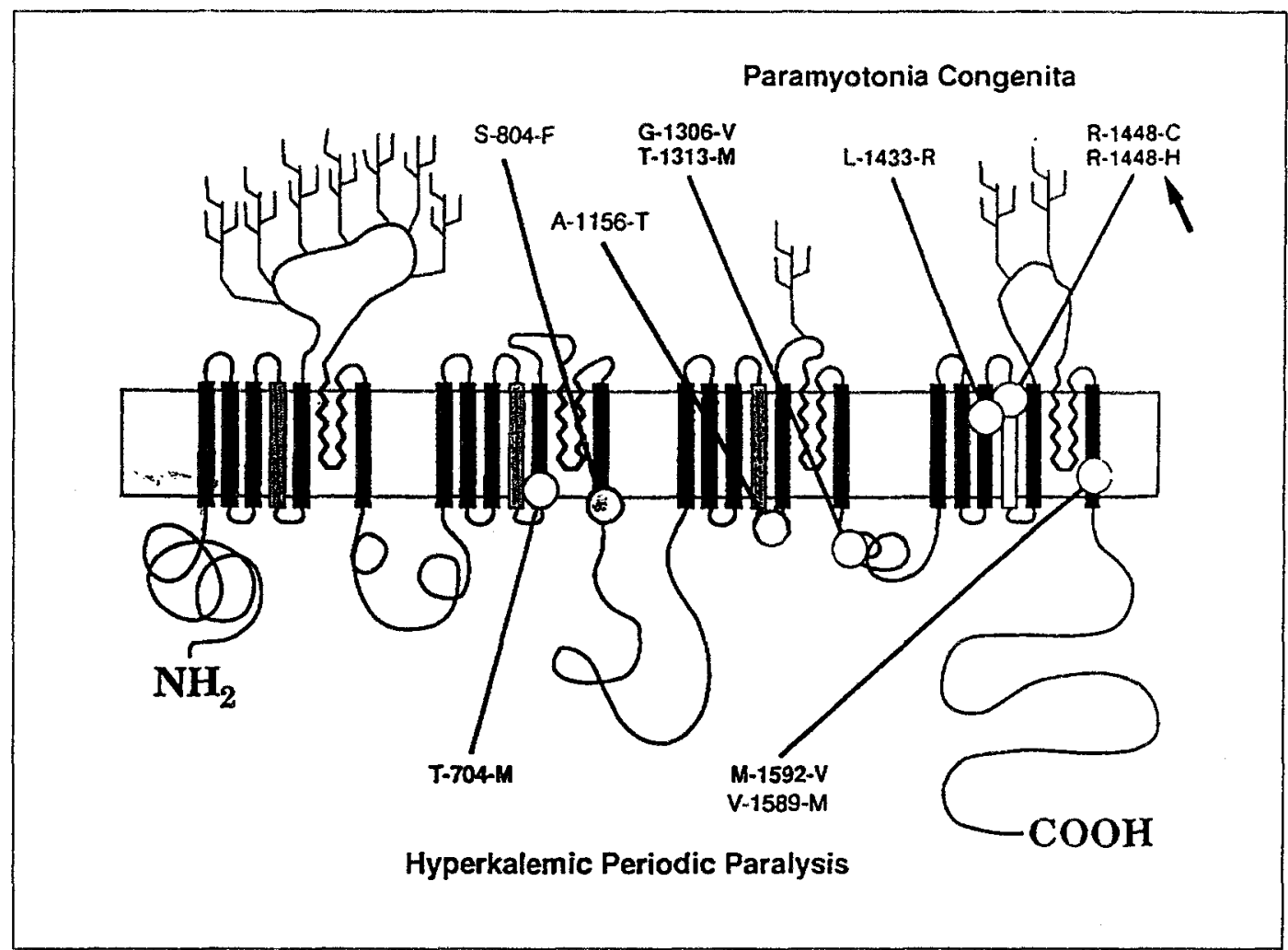

Fig. 3. A sodium channel model indicating the sodium channel mutations so far identified in patients with PC and HYPP phenotypes. The location of the mutations is shown and named using the one-letter code for the normal amino acid, followed by the position (amino acid number) of the mutation and the one-letter code for the amino acid at that position in the mutant. The arrow in the figure refers to our family's mutation and indicates that, at position 1448 in the sodium channel protein, arginine is replaced by hystidine, thus leading to the PC phenotye described. All of the family members examined present this mutation.

$M=$ methionine; $T=$ threonine; $R=$ arginine; $H=$ hystidine; $C=$ cysteine; $G=$ glycine; $V=$ valine; $L=$ leucine.

thought to serve as the inactivation gate of the channel, it is possibile that the conformation of the protein resulting from the depolarization of the membrane may influence the inactivation of the channel.

This mutation has never before been described in Italy. This is important because, although molecular genetic studies have contributed to the reclassification of these disorders, it is now necessary to consider the prevalence of the different phenotypes so far described and attempt a more precise therapeutic approach. The number of families studied at a molecular level is still too small to draw definitive conclusions. Studies of more families from different ethnic backgrounds might help to establish a correlation between genotype and phenotype. Once the precise alteration in the channel is identified, patch-clamp studies might improve our understanding of how this affects channel gating in both normal and diseased mus- cle, and available drugs such as mexiletine, potassium-sparing agents, carbonic anhydrase inhibitors, etc. might then be more specifically used $[14,30]$ according to the channel involved and the degree of channel gating involvement [27].

In agreement with previous reports concerning other PC families [1] and the recently described acetazolamide-responsive myotonia congenita (another disorder linked to the sodium channel gene but in which no mutation has yet been demonstrated) [24] we have started treating the patients in our family with mexiletine (which raises the threshold level of the action potential to more positive values and should prevent persistent depolarization).

Further controls are needed to confirm the success of this therapeutic approach, as well as to correlate specific clinical features with distinct mutations in an attempt to improve our understanding of channel gating and channel malfunc- 
tion in periodic paralysis. This understanding can then be translated into improved methods of diag- nosis and treatment for patients with non-dystrophic myotonic disorders.

Acknowledgment:We would like to thank Alasdair McEwen for having read and revised the text for any error in English syntax and grammar.

\section{Sommario}

Le paralisi periodiche costituiscono un gruppo di miopatie a carattere autosomico dominante caratterizzate da episodi transitori crampiformi e da ipostenia. La sintomatologia descritta è scatenata solitamente da eccessiva esposizione di alcuni segmenti corporei (solitamente mani, piedi ed orbicolare degli occhi) alle basse temperature (come si verifica nei casi di paramiotonia congenita, $P C$ ) oppure da variazioni spontanee o indotte del potassio extracellulare (come si verifica nei casi di paralisi iper-, HYPP o ipokaliemica, HypoPP).

E ormai noto che il gene responsabile per le forme di HYPP e di PC è localizzato sul cromosoma 17 $e$ le variazioni fenotipiche correlate indicano che vi sono varianti alleliche di tali disordini. Finora queste forme sono state descritte in numerosi gruppi etnici ma non sono mai state riconosciute in Italia.

Descriviamo una mutazione del segmento S4 del canale muscolare umano del sodio in una famiglia italiana con un fenotipo caratteristico per una paramiotonia congenita, a trasmissione autosomica dominante, interessante tutti i membri della famiglia da noi studiata fin dalla giovane età.

\section{References}

[1] Borg K., Hovmoller M., Larsson L., EdSTROM L.: Paramyotonia congenita (Eulenburg): clinical, neurophysiological and muscle biopsy observations in a Swedish family. Acta Neurol. Scand. 87:37-42, 1993.

[2] Bulman D.E., Tollar L.L., Murray J.D., ALLON M., Cousin H.K., Crackower M.A., HudSON A.J., EBERS G.C.: Hypokalemic periodic paralysis is linked to the alpha-1 subunit of the dihydropyridine sensitive calcium channel at 1q31-32. Works in Progress for Expedited Presentation, 46th Annual Meeting of the American Academy, Washington, 1994.

[3] Casley W.L., Allon M., Cousin H.K., et al.: Exclusion of linkage betieen hypokalemic periodic paralysis (HOKPP) and three candidate loci. Genomics, 14:493-494, 1992.

[4] Duвowitz V.: Muscle biopsy: A practical approach, 2nd ed. Baillière. Tindall, London, 1985.

[5] Ebers G.C., GeORGe A.L., Barchi R.L., ET AL.: Paramyotonia congenita and hyperkalemic periodic paralysis are linked to the adult sodium channel gene. Ann. Neurol. 30:810-816, 1991.

[6] Feero W.G., Wand J.. Barany F., Zhou J., ET AL.: Hyperkalemic periodic paralysis: rapid molecular diagnosis and relationship of genotype of phenotype in 12 families. Neurology, 43:668-673, 1993.

[7] Fontaine B., Khurana T.S.. Hoffmann E.P., ET AL.: Hyperkalemic periodic paralysis and the adult muscle sodium channel alpha-subunit gene. Science, 250:1000-1002. 1990.

[8] Fontaine B., Trofatter J., Rouleau G.A., ET
AL.: Genetic heterogeneity in periodic paralysis. Neuromusc. Dis. 1:235-238, 1991.

[9] FonTAINe B.: Periodic paralysis, myotonia congenita and sarcolemmal ion channels: a success of the candidate gene approach. Review article, Neuromusc. Dis., Vol. 3, 2:101-107, 1993.

[10] George A.L., Ledbetter D.H., Kallen R.G., BARCHI R.L.: Assignment of a human skeletal sodium channel alpha-subunit gene (SCN4A9 to 17q23.1-25.3). Genomics 9:555-556, 1991.

[11] GRigGs R.C.: The myotonic disorders and periodic paralysis. Adv. Neurol. 17:143-159, 1977.

[12] Iaizzo P.A., Franke Ch., HatT H., ET AL.: Altered sodium channel behaviour causes myotonia in dominantly inherited myotonia congenita. Neuromuscular Dis., Vol. 1, 1:47-53, 1991.

[13] KOCH M.C., RickeR K., OTTO M., ET AL.: Linkage data suggesting allelic heterogeneity for paramyotonia congenita and hyperkalemic periodic paralysis on chromosome 17. Hum. Gen. 88:71-74, 1991.

[14] KWIECINSKI H., RYNIEWIEZ B., OsTRZYCKI A.: Treatment of myotonia with antiarhythmic drugs. Acta Neurol. Scand.. 86:371-375, 1992.

[15] LEHMANN-HORN F., KUTHER G.. RickeR K., ET AL.: Adynamia episodica hereditaria with myotonia: a non-inactivating sodium current and the effects of extra-cellular $p H$. Muscle \& Nerve 10:363374, 1987.

[16] Lehmann-Horn F., Ialzzo P.A., Hatt H., FRANKE Ch.: Altered gating and conductance of Na channels in hyperkalemic periodic paralysis. Pflugers Arch 418:297-299, 1991.

[17] MCClatchey A., VAN DER Bergh P., PeriCaKVANCE M., ET AL.: Temperature-sensitive muta- 
tions in the III-IV cytoplasmic loop region of the skeletal muscle sodium channel gene in paramyotonia congenita. Cell 68:769-774, 1992.

[18] McClatchey A., McKenna-Yasek D., Cros D., ET AL.: Novel mutations in families with usual and variable disorders of the skeletal muscle sodium channel. Nature Gen. 2:148-152, 1992.

[19] PTACEK L.J., TRIMmer J.S., AGNEW W.S., ET AL.: Paramyotonia congenita and hyperkalemic periodic paralysis map to the same sodium channel gene locus. Am. J. Hum. Gen. 49:851-854, 1991.

[20] PTACEK L.J., George A.L., GRIGGS R.C., ET AL.: Identification of a mutation in the gene causing hyperkalemic periodic paralysis. Cell 67:1021$1027,1991$.

[21] Ptacex L.J., George A.L., Barchi R.L., et AL.: Mutations in an S4 segment of the adult skeletal muscle sodium channel cause paramyotonia congenita. Neuron. 8:891-897, 1992.

[22] Ptacek L.J., Keith M.D., Johnson K.J., Griggs R.C.: Genetics and physiology of the myotonic muscle disorders. Review article. New Engl. J. Med. 328:482-489, 1993.

[23] Ptacek L.J., Gouw L., Kwiecinski H., et AL.: Sodium channel mutations in paramyotonia congenita and hyperkalemic periodic paralysis. Ann.
Neurol. 33:300-307, 1993.

[24] Ptacek L.J., Tawil R., Griggs C., Meola G., et AL.: Sodium channel mutations in acetazolamideresponsive myotonia congenita, paramyotonia congenita and hyperkalemic periodic paralysis. Neurology 44:1500-1503, 1994.

[25] Rojas C.V., Wang J., SChWartz L.S., et al.: A met-to-val mutation in the skeletal muscle $\mathrm{Na}+$ channel alpha-subunit in hyperkalemic periodic paralysis. Nature 354:387-389, 1991.

[26] RUDEL R., RICKER K.: The primary periodic paralyses. TINS 8:467-470, 1985.

[27] DE SiL.va S.M., KunCL R.W., GRIFFIN J.W., ET AL. Paramyotonia congenita or hyperkalemic periodic paralysis? Clinical and electrophysiological features of each entity in one family. Muscle \& Nerve 13:21-26, 1990 .

[28] Sanger F., Nicken S., Coulson A.: DNA sequ. encing with chain-terminating inhibitors. Proc. Natl. Sci. USA 74:5463-5467, 1977.

[29] STREIB E.W.: Differential diagnosis of myotonic syndromes. Muscle \& Nerve 10:603-615, 1987.

[30] STreib E.W.: Paramyotonia congenita: successful treatment with tocainide. Clinical and electrophysiologic findings in seven patients. Muscle \& Nerve 10:155-162, 1987.

Address reprint requests to: Prof. G. Meola, Primario della Divisione di Neurologia I, Ospedale di San Donato, Via Morandi 30, San Donato Milanese, Milano - Italy 